\title{
Unestablished Businesses and Treble Damage Recovery Under Section Four of the Clayton Act
}

Persons "injured in their business or property by reason of anything forbidden in the antitrust laws" may bring a private treble damage action under section 4 of the Clayton Act. ${ }^{2}$ Courts differ as to whether a person can recover damages when his losses result not from damage to an operative venture, but from foreclosure of a business venture that is in a conceptual or planning stage. ${ }^{3}$ For example, the individual may have a plan for a business but lack such operational necessities as a plant, raw materials, employees, or customers. ${ }^{4}$ A minority of courts refuse to award dam-

15 U.S.C. \$ 15 (1976 \& Supp. IV 1980).

2 Clayton Act $\S 4,15$ U.S.C. $\S 15$ (1976 \& Supp. IV 1980). Section 4 provides in pertinent part:

Any person who shall be injured in his business or property by reason of anything forbidden in the antitrust laws may sue therefor in any district court of the United States in the district in which the defendant resides or is found or has an agent, without respect to the amount in controversy, and shall recover threefold the damages by him sustained, and the cost of suit, including a reasonable attorney's fee.

Id. As amended in 1980, the statute also allows litigants to recover prejudgment interest on actual damages. $I d$.

Section 4 is a recodification of $\S 7$ of the Sherman Antitrust Act, which provided a private remedy in essentially the same terms:

Any person who shall be injured in his business or property by any other person or corporation by reason of anything forbidden or declared to be unlawful in this act, may sue therefor in any circuit court of the United States in the district in which the defendant resides or is found, without respect to the amount in controversy, and shall recover three fold the damages by him sustained, and the costs of suit, including a reasonable attorney's fee.

Sherman Antitrust Act, ch. 647, \& 7, 26 Stat. 209, 210 (1890) (repealed 1955) (substantially similar language in Clayton Act, codified at 15 U.S.C. $\$ 15$ (1976)).

Section 16 of the Clayton Act allows private injunctive relief. 15 U.S.C. $\$ 26$ (1976). See infra notes 34-38 and accompanying text.

See infra notes 5-8 and accompanying text. See generally 2 P. Areeda \& D. Turner, ANTITRUST LAW I 335(c), at 174-75 (1978). This debate becomes increasingly important as the number of private antitrust actions brought each year rises. In 1980, 1457 private antitrust actions were filed in U.S. district courts, compared to 228 in 1960. ADMINISTRATIVE Office of the United States Courts, 1980 Annual Report of the Director 63 (1980).

- The venture in such circumstances is generally referred to as an unestablished business. Courts offer little help in defining the term "unestablished business," although they all use the terms "established" and "unestablished" to describe the dichotomy discussed in this comment. These terms were first used in Central Coal \& Coke Co. v. Hartman, 111 F. 96 (8th Cir. 1901). In Central Coal, the court noted that damages for future profits are gener- 
ages in such circumstances, concluding that there is no business to be harmed. ${ }^{5}$ Even when a venture operates for a short time before being driven out of business by an antitrust violation, the minority position refuses to award damages for lost profits because the venture lacks a sufficient profit history upon which to base an award. ${ }^{\circ}$ Most courts, however, assert a willingness to compensate unestablished businesses for business losses such as lost profits ${ }^{7}$ because "[i]t is as unlawful to prevent a person from engaging in business as it is to drive a person out of business."

ally too speculative to award, but stated that plaintiffs may recover lost future profits in cases involving "destruction or interruption of an established business," provided that the plaintiffs offered competent proof of these damages. Id. at 98. The court justified this exception to the rule against prospective lost profits damages on the ground that long-established businesses could prove their capital, usual expenses, and profits for the time both before and during the violation. Id. This suggests that an "established business" would be one that not only had secured adequate capital, facilities, supplies, and personnel to begin operation, but had also been operational long enough to establish levels of "usual" expenses and profits.

For purposes of this comment, an established business is one that currently exists on a firm, operational basis, with enough of a business history that usual expenses and profits can be proved. An unestablished business is any venture that lacks operational necessities, such as facilities, raw materials, personnel, or customers, or that has obtained these necessities so recently that data on "usual" expenses and profits cannot be collected. Given the annual nature of accounting cycles, the heading "unestablished" could include ventures that have been in operation for up to one year. The term "unestablished business" also includes expansions by existing firms into new product or service lines. See, e.g., Laurie Visual Etudes, Inc. v. Chesebrough-Pond's, Inc., 473 F. Supp. 951, 956-57 (S.D.N.Y. 1979). In Laurie, a firm with 20 years of experience in the music and record industry desired to enter the medical field by marketing a medical breath exercise device. The court treated the proposed expansion as an unestablished venture. Id.

s See, e.g., Duff v. Kansas City Star Co., 299 F.2d 320, 325 (8th Cir. 1962); Central Coal $\&$ Coke Co. v. Hartman, 111 F. 96, 99 (8th Cir. 1901); Cohen v. Curtis Publishing Co., 229 F. Supp. 354, 364 (D. Minn. 1963), appeal dismissed, 333 F.2d 974 (8th Cir. 1964), cert. denied, 380 U.S. 921 (1965). Some courts outside the Eighth Circuit have espoused this narrow view of $\$ 4$ and have also limited the term "business" to established ventures. E.g., LaRouche v. United Shoe Mach. Corp., 166 F. Supp. 633, 635 (D. Mass. 1958).

- See, e.g., National Wrestling Alliance v. Myers, 325 F.2d 768, 775-77 (8th Cir. 1963) (noting plaintiff's meager evidence of business history and holding plaintiff's claim too speculative to support damage award of lost future profits).

7 See, e.g., Hayes v. Solomon, 597 F.2d 958, 973 (5th Cir. 1979) (plaintiff can sue for harm to unestablished business if he intended to start business and was prepared to do so), cert. denied, 444 U.S. 1078 (1980); Martin v. Phillips Petroleum Co., 365 F.2d 629, 633 (5th Cir.) (plaintiff need not have ongoing business; attempt to enter a business is sufficient), cert. denied, 385 U.S. 991 (1966); Triangle Conduit \& Cable Co. v. National Elec. Prods. Corp., 152 F.2d 398, 399 (3d Cir. 1945) (necessary to allege intent and preparedness to engage in business); Fleer Corp. v. Topps Chewing Gum, Inc., 415 F. Supp. 176, 181 (E.D. Pa. 1976) (allegation of intent and preparedness to engage in business is sufficient to give plaintiff standing under $\S 4$ to sue for harm to the nascent venture). See generally 2 P. AREEDA \& D. TURNER, supra note 3 , II 335 , at 174-75.

- Thomsen v. Union Castle Mail S.S. Co., 166 F. 251, 253 (2d Cir. 1908). See also Fleer Corp. v. Topps Chewing Gum, Inc., 415 F. Supp. 176, 180-81 (E.D. Pa. 1976); Delaware 
This comment examines the language and history of the Clayton Act, as well as the policies underlying the Act, and finds that these considerations compel neither the majority nor the minority approach. Awarding lost profits to nascent ventures exceeds the intended reach of section 4 and may deter socially beneficial behavior, ${ }^{9}$ but denying any award to an entrepreneur who is kept out of business by an antitrust violation does not adequately serve the Clayton Act's goals of deterring and punishing antitrust violations. ${ }^{10}$ The comment suggests that the deficiencies of both approaches stem from their focus on whether there has been a loss to "business." The comment concludes that it is more in keeping with the language and purposes of section 4 to disregard the possibility of business losses to unestablished ventures and to focus instead on whether the entrepreneur has suffered an injury to his "property." Courts applying section 4 should award damages to unestablished ventures only for losses to property.

\section{STATUTORY INTERPRETATION}

Plaintiffs in section 4 actions $^{11}$ typically seek to recover future profits they will allegedly lose due to the defendant's antitrust violations. ${ }^{12}$ When the plaintiff is driven from a business he has been operating for some time, his profit record provides a reasonable basis from which to infer that the antitrust violation will diminish his future profits. ${ }^{13}$ An unestablished business, however, has no record

Valley Marine Supply Co. v. American Tobacco Co., 184 F. Supp. 440, 443 (E.D. Pa. 1960), aff'd, 297 F.2d 199 (3d Cir. 1961), cert. denied, 369 U.S. 839 (1962).

- See 2 P. AREedA \& D. Turner, supra note 3, I 335, at 174.

10 Note, Private Treble Damage Antitrust Suits: Measure of Damages for Destruction of All or Part of a Business, 80 HArv. L. REv. 1566, 1566-67 (1967). Many feel that deterrence is the first, and probably the only, goal of antitrust damages and that a damage award that happens to compensate an injured party is merely a happy coincidence. See, e.g., Easterbrook, Predatory Strategies and Counterstrategies, 48 U. CHI. L. REv. 263, 319 (1981).

11 Antitrust violations are of three main types: violations that tend toward cartels, such as price fixing, which fall within $\S 1$ of the Sherman Act, 15 U.S.C. $\$ 1$ (1976); violations that tend toward monopoly, such as predatory pricing, boycotts, and tying arrangements, which fall within $\S 2$ of the Sherman Act, 15 U.S.C. $\$ 2$ (1976); and violations resulting from the merger of competitors, largely covered under $\S 7$ of the Clayton Act, 15 U.S.C. $\S 18$ (Supp. IV 1980). See generally R. Posner, ANTITRUST Law: AN Economic Perspective 23-35 (1976). Private actions under § 4, see supra note 2, may seek remedies for cartelization, monopolization, or illegal mergers.

${ }_{12}$ See, e.g., cases cited supra notes $5,8$.

13 Indeed, the "before and after" damage estimate is commonly used by established ventures to quantify their harms. This kind of analysis only works for an ongoing, established venture with a record of past performance. See Hoyt, Dahl \& Gibson, Comprehensive Models for Assessing Lost Profits to Antitrust Plaintiffs, 60 Mins. L. REv. 1233, 1233-36 (1976); Parker, Measuring Damages in Federal Treble Damage Actions, 17 Anritrust 
of operations and profits upon which to base predictions of future losses. And the high failure rate of new businesses makes it even more difficult to relate the losses of an unestablished business to an antitrust violation; it is more likely that an unestablished business would never have been profitable than that it would lose profits due to an antitrust violation. ${ }^{14}$ Despite this problem, most courts define "business" broadly" and interpret the "injury to business" portion of section $4^{16}$ to permit awards of lost future profits to unestablished business ventures. These courts allow recovery to those plaintiffs who can show both intent and preparedness to engage in the venture. ${ }^{17}$ Two possible justifications for such an ex-

Bull. 497, 501 (1972); Rulon, Proof of Damages for Terminated or Precluded Plaintiffs, 49 ANTITRUst L.J. 153, 159 (1980).

14 Researchers have shown that $95 \%$ of all new businesses eventually terminate, discontinue, go bankrupt, reorganize, or exit for other reasons. See Star \& Massel, Survival Rates for Retailers, $57 \mathrm{~J}$. RETAMING 87, 88 (1981). In fact, the first years of a company's operations are the most uncertain. One study showed that in retailing, a high-turnover industry, only $35.1 \%$ of new ventures survive through the fifth year. Id. at 93 (Table 2). Dun \& Bradstreet notes that of 7919 business failures in 1977, over half were five years old or younger. BuSIness and Economics Division of Dun \& Bradstreet, Inc., The Business Failure Record FOR 1977, at 2, 10 (1978). On problems in use of the term "failure" in these statistics, see generally Cochran, Small Business Mortality Rates: A Review of the Literature, $19 \mathrm{~J}$. Small Bus. Mgmt. 50 (1981).

1s For example, the Seventh Circuit defined the word "business" as

that which habitually busies, or engages, time, attention or labor, as a principal serious concern or interest. In a somewhat more truly economic, legal and industrial sense, it includes that which occupies the time, attention, and labor of men for the purpose of livelihood or profit,-persistent human efforts which have for their end pecuniary reward. It denotes "the employment or occupation in which a person is engaged to procure a living."

Roseland v. Phister Mfg. Co., 125 F.2d 417, 419 (7th Cir. 1942) (quoting Allen v. Commonwealth, 188 Mass. 59, 61, 74 N.E. 287, 288 (1905)). The Second Circuit referred to business as

"the occupation, the engaging, the doing of the varied commercial acts, and the taking of the requisite steps from which result conclusions and conditions." ... "[Business] means the activity, the energy, the capacity, the opportunities by which results are reached-a condition rather than fixed tangible objects for which conditions arise."

Sullivan v. Associated Billposters \& Distribs. of the United States \& Can., 6 F.2d 1000, 1010 (2d Cir. 1925) (quoting Atlantic Postal Tel.-Cable Co. v. Mayor of Savannah, 133 Ga. 66, 7374,65 S.E. 184,188 (1909)).

16 See supra note 1 and accompanying text.

${ }_{17}$ See supra note 7. Some commentators assert that the Supreme Court held unestablished businesses eligible to sue under the antitrust laws in American Banana Co. v. United Fruit Co., 213 U.S. 347 (1909). See Collen, Procedural Directions in Antitrust Treble Damage Litigation: An Overview of Changing Judicial Attitudes, 17 ANTITRust Bull. 997, 1025 (1972); Comment, Standing Under Clayton \& 4: A Proverbial Mystery, 77 Dick. L. Rev. 73, 90 (1972). The Supreme Court did affirm the Second Circuit decision, which held, inter alia, that " it is as unlawful to prevent a person from engaging in business as it is to drive a person out of business." " 166 F. 261, 264 (2d Cir. 1908) (quoting Thomsen v. Union Castle Mail S.S. Co., 166 F. 251, 253 (2d Cir. 1908)). The Supreme Court, however, dealt not with 


\section{pansive reading of section 4 are the specific language and history of the Clayton Act and the general deterrence theory of antitrust law. ${ }^{18}$}

this issue but with the jurisdiction of the circuit court to hear a case concerning acts done outside the United States. The circuit court had affirmed the trial court's dismissal of the complaint for failure to state a cause of action on this basis, American Banana Co., 166 F. at 267, and the Supreme Court affirmed. Thus, the private antitrust remedy was never at issue and was not even addressed in dicta by the Court.

The Supreme Court has dealt with some aspects of standing in the antitrust area. For example, the Court addressed the ability of indirect purchasers to sue for damages in Illinois Brick Co. v. Illinois, 431 U.S. 720 (1977) (indirect purchasers not allowed to sue under $\$ 4$ ). See also Landes \& Posner, Should Indirect Purchasers Have Standing to Sue Under the Antitrust Laws? An Economic Analysis of the Rule of Illinois Brick, 46 U. CHI. L. Rev. 602 (1979). The analysis of Illinois Brick, however, amounted to a debate over which of two possible plaintiffs (direct or indirect purchasers) should be given standing to sue to redress a single antitrust violation. The unestablished-business question, by contrast, concerns whether an entire class of harms caused by any kind of antitrust violation should be remedied by $\S 4$ 's treble damage action at all. Thus, analogy to these authorities is inappropriate.

18 Constitutional standing requirements place a threshold limitation on the ability of unestablished businesses to recover under $\S 4$. The Constitution grants the federal courts power to decide only "cases" and "controversies." U.S. CoNST. art. III, $§ 2$. The courts have long read this as limiting their power to hear only justiciable cases in an adversarial context, and this has given rise to standing requirements. C. Wright, A. Miller \& E. COOPER, 13 Federal Practice and Procedure § 3531 (1975).

To bring a suit in federal court, a plaintiff must meet two conditions. First, he must allege that he was injured in fact, thereby demonstrating that he has "a personal stake in the outcome of the controversy." Baker v. Carr, 369 U.S. 186, 204 (1962). See also Village of Arlington Heights v. Metropolitan Hous. Dev. Corp., 429 U.S. 252, 260-61 (1976); Flast v. Cohen, 392 U.S. 83, 99 (1968). Second, he must demonstrate a causal connection between his injury and the defendant's actions. Village of Arlington Heights, 429 U.S. at 261. The plaintiff has the burden of proof of causation. See $i d$. The plaintiff has a similar burden in the context of antitrust standing. See Brunswick Corp. v. Pueblo Bowl-O-Mat, Inc., 429 U.S. 477, 489 (1977); Zenith Radio Corp. v. Hazeltine Research, Inc., 395 U.S. 100, 114 n.9 (1969); California Computer Prods. v. IBM, 613 F.2d 727, 732 (9th Cir. 1979).

Many courts refer to the "business or property" language as a standing requirement. See, e.g., Pan-Islamic Trade Corp. v. Exxon Corp., 632 F.2d 539, 546 (5th Cir. 1980), cert. denied, 454 U.S. 927 (1981); Solinger v. A\&M Records, Inc., 586 F.2d 1304, 1309 (9th Cir.), cert. denied, 441 U.S. 908 (1978); Tugboat, Inc. v. Mobile Towing Co., 534 F.2d 1172, 1174 (5th Cir. 1976); Laurie Visual Etudes, Inc. v. Chesebrough-Pond's, Inc., 473 F. Supp. 951, 955 (S.D.N.Y. 1979); Fleer Corp. v. Topps Chewing Gum, Inc., 415 F. Supp. 176, 179 (D. Del. 1971); N.W. Controls, Inc. v. Outboard Marine Corp., 333 F. Supp. 493, 506 (D. Del. 1971). Commentators sometimes refer to the $\S 4$ language as a standing requirement also. See, e.g., 2 P. AREEDA \& D. Turner, supra note 3, II 334, at 163-70; Klingsberg, Bull's Eyes and Carom Shots: Complications and Conflicts on Standing to Sue and Causation Under Section 4 of the Clayton Act, 16 Antrtrust Bull. 351, 352 (1971); 3 W. NEw Eng. L. Rev. 81,86 (1980). This reference is inapt, however, since the true standing threshold in the constitutional sense involves only injury-in-fact and causation, as indicated in the discussion above.

The Supreme Court recently discussed standing under $\S 4$ and reaffirmed that "Congress did not intend to allow every person tangentially affected by an antitrust violation to maintain an action to recover threefold damages for the injury to his business or property." Blue Shield v. McCready, 102 S. Ct. 2540, 2547 (1982). To effectuate this limited intent, the Court proposed a two-part test to determine the sufficiency of the causal link: 


\section{A. The Statute}

The language of section 4 is sweeping and general. Its authorization for "any person" to "sue . . . in any district court . . . without respect to the amount in controversy"10 suggests a broad remedial purpose. Courts have used this language as the basis of an expansive interpretation of the statute, ${ }^{20}$ but such an interpretation ignores the express limits contained in section 4 . The statute remedies injury only to "business or property by reason of anything forbidden in the antitrust laws."21 A basic principle of statutory construction is that nontechnical terms of a statute should be given their usual meaning. ${ }^{22}$ The broad construction of the term

[W]e look (1) to the physical and economic nexus between the alleged violation and the harm to the plaintiff, and, (2) more particularly, to the relationship of the injury alleged with those forms of injury about which Congress was likely to have been concerned in making defendant's conduct unlawful and in providing a private remedy under $\S 4$.

Id. at 2548. The Court's language, however, gives lower courts little guidance in applying the test. Prior to $\mathrm{McCready}$, lower courts devised tests based on the directness of the injury, its foreseeability, or its presence within the defendant's target area. Id. at $2547 \mathrm{n} .12$. Because the Supreme Court refused "to evaluate the relative utility of any of these possibly conflicting approaches," id., it is unclear how the lower courts will respond. For a description of lower court tests prior to McCready, see 2 P. AREEDA \& D. Turner, supra note 3, II 334(d); Alioto \& Donnici, Standing Requirements for Antitrust Plaintiffs: Judicially Created Exceptions to a Clear Statutory Policy, 4 U.S.F.L. REv. 205, 212-14 (1970).

This comment assumes that the unestablished businesses considered here can satisfy the constitutional standing requirements and that the defendants have indeed violated the antitrust laws, thereby harming the plaintiffs. The questions the comment addresses are strictly statutory: does $\S 4$ provide a remedy for unestablished businesses, and, if so, what is that remedy?

10 Clayton Act \& 4, 15 U.S.C. \& 15 (1976) (emphasis added).

${ }^{20}$ E.g., Blue Shield v. McCready, 102 S. Ct. 2540, 2545 (1982); Reiter v. Sonotone Corp., 442 U.S. 330, 337 (1979) ("On its face, $\$ 4$ contains little in the way of restrictive language."); Hoopes v. Union Oil Co., 374 F.2d 480, 486 (9th Cir. 1967). In Hoopes, the court used $\S 4$ 's broad language as the basis for its conclusion that the Clayton Act is "comprehensive in its terms and coverage, protecting all who are made victims of the forbidden practices by whomever they may be perpetrated.' "Id. (quoting Mandeville Island Farms v. American Crystal Sugar Co., 334 U.S. 219, 236 (1948)).

2115 U.S.C. $\$ 15$ (1976). The Supreme Court has characterized the "by reason of" language as a limitation on the kinds of harm remedied by $\S 4$. Brunswick Corp. v. Pueblo Bowl-O-Mat, Inc., 429 U.S. 477, 488 (1976); see also In re Indus. Gas Antitrust Litig., 681 F.2d 514, 520 (7th Cir. 1982). The "business or property" language is also a limit, narrowing the class of injuries for which $\S 4$ 's treble damage awards are available. Reiter v. Sonotone Corp., 442 U.S. 330, 339 (1979) ("business or property" language is restrictive); Zenith Radio Corp. v. Matsushita Elec. Indus. Co., 513 F. Supp. 1100, 1157-58 (E.D. Pa. 1981). See also 2 P. AREedA \& D. TURNER, supra note 3, I 333, at 161 (noting that " "business or property,", "[a]lthough imprecise, . . . are words of limitation").

${ }^{22}$ Addison v. Holly Hill Fruit Prods. Co., 322 U.S. 607, 618 (1944) (when legislation is not expressed in technical terms, words must be given the meaning an ordinary man would give them). 
"business" in section 4 is contrary to the common, everyday definitions of that term. ${ }^{23}$ It is contradictory for a court to require that "business" be given its usual meaning, ${ }^{24}$ yet compensate a "business" that has not exchanged any goods or services and that consists of a single experienced person, some money, and a contract. ${ }^{25}$

A selective reading of the legislative history of the Clayton Act, however, lends some support to a broad construction of section 4. When passed in $1914,{ }^{28}$ the private remedies provided in sections 4 and 16 of the Act $^{27}$ were intended to strengthen existing remedies. ${ }^{28}$ Some supporters felt the Act would greatly expand the private remedies. Representative $\mathrm{Webb}$, for example, explained that the section that became section 4 "opens the door of justice to every man, whenever he may be injured by those who violate the antitrust laws, and gives the injured party ample damages for the wrong suffered."29 Since then, the Supreme Court has noted the section's broad scope and stated that it provides a cause of action for all who are victims of antitrust violations. ${ }^{30}$ It is conceivable,

${ }^{23}$ Common definitions of business describe it as a "commercial or mercantile activity customarily engaged in as a means of livelihood," WEBSTER's ThIRD NEw INTERNATIONAL DictionARY 302 (4th ed. 1976), and "[t]hat which habitually busies or occupies or engages the time, attention, labor, and effort of persons, as a principal serious concern or interest or for livelihood or profit," Black's Law Dictionary 179 (rev. 5th ed. 1979). The definitions' verb tenses and word choices support the common-sense notion that "businesses" are operating, commercial ventures.

${ }^{24}$ For examples of courts requiring that "business" have its usual meaning, see Hawaii v. Standard Oil Co., 431 F.2d 1282, 1285 (9th Cir. 1970), aff'd, 405 U.S. 251 (1972); Roseland v. Phister Mfg. Co., 125 F.2d 417, 419 (7th Cir. 1942); Image \& Sound Serv. Corp. v. Altec Serv. Corp., 148 F. Supp. 237, 239 (D. Mass. 1956).

${ }_{25}$ These minor steps can qualify a venture as a business under the intent and preparedness test. See infra notes $81-89$ and accompanying text.

${ }^{28}$ The chronology of the Act's passage is found in 2 The Legislative History of the Federal Antitrust Laws and Related Statutes 1026-37 (E. Kintner ed. 1978) [hereinafter cited as Legislative History].

${ }^{27}$ Clayton Act, ch. 323, $§ \$ 4,16,38$ Stat. 730, 731, 737 (1914) (codified as amended at 15 U.S.C. $\S \S 15,26$ (1976 \& Supp. IV 1980)). See supra note 2.

${ }^{28}$ Levy, The Clayton Law-An Imperfect Supplement to the Sherman Law, 3 VA. L. REv. 411, 415-17 (1916). The Clayton Act also strengthens private remedies by allowing final judgments in actions brought by the United States to serve as prima facie evidence against the same defendant in subsequent private actions. See Clayton Act § 5, 15 U.S.C. $§ 16$ (1976 \& Supp. IV 1980).

${ }^{29} 51$ CoNG. REc. 9073 (1914) (remarks of Rep. Webb), reprinted in 2 LEgislative HisTORY, supra note 26, at 1192. Representative Webb became Chairman of the House Judiciary Committee, in which the bill originated, when former Chairman Clayton resigned to accept a federal judgeship three days after Webb made these remarks. 2 LEgisLative HisTORY, supra note 26 , at 1003-04.

30 Mandeville Island Farms, Inc. v. American Crystal Sugar Co., 334 U.S. 219, 236 (1948) ("The Act is comprehensive in its terms and coverage, protecting all who are made victims of the forbidden practices by whomever they may be perpetrated." (citation omit- 
then, that the Act provides a lost profits remedy for unestablished businesses.

The legislative history, however, does not clearly support such a broad interpretation. ${ }^{31}$ Legislators considering the Clayton Act expressed concern about in terrorem use of private treble damage actions. They objected to certain provisions which they feared would allow an unhealthy expansion of the private remedy..$^{32} \mathrm{Im}$ plicit in these concerns is the idea that treble damages should not be awarded easily. Consistent with these statements, virtually all federal courts, including the Supreme Court, agree that "Congress did not intend the antitrust laws to provide a remedy in damages for all injuries that might conceivably be traced to an antitrust violation."

Further support for a narrow construction of section 4 comes from an examination of the Clayton Act in its entirety. Section 16 of the Act allows private litigants to seek injunctions to stop any threatened injury, ${ }^{34}$ not just injuries to business or property. Although the legislative history does not explain why Congress included the "business or property" language in section 4 alone, ${ }^{35}$ "[t]he most likely explanation lies in the essential differences between the two remedies." ${ }^{\text {"36 }}$ Multiple injunctions usually affect a defendant no differently than a single injunction would because he will have to behave identically whether ordered to do so once or many times. In contrast, multiplication of treble damage awards magnifies the liability to which the defendant is subject. ${ }^{37}$ Accord-

ted)), quoted in Blue Shield v. McCready, $102 \mathrm{~S}$. Ct. 2540, 2545 (1982).

${ }^{31}$ See Reiter v. Sonotone Corp., 442 U.S. 330, 342-43 (1979) ("Nowhere in the legislative record is specific reference made to the intended scope of those terms.").

32 The provision allowing the admission of a final judgment in a government suit as conclusive evidence in a private suit for a related violation, H.R. 15,657, 63d Cong., 2d Sess. $\S 5$ (1914), reprinted in 2 LegisLative History, supra note 26, at 1082, was the subject of "serious objection." H.R. REP. No. 627, (pt. 2), 63d Cong., 2d Sess. 9-10 (1914) (minority views), reprinted in 2 Legislative HistoRy, supra note 26, at 1131. This provision was amended in later debate on the bill to allow the final judgment in a government suit to serve as prima facie evidence in a related private suit. See 51 Cong. REc. 13,907 (1914), reprinted in 2 Legislative History, supra note 26, at 1835-36; see also supra note 28.

${ }^{33}$ Hawaii v. Standard Oil Co., 405 U.S. 251, 263 n.14 (1972). See also Blue Shield v. McCready, 102 S. Ct. 2540, 2547-48 (1982); In re Indus. Gas Antitrust Litig., 681 F.2d 514, 515 (7th Cir. 1982); Tugboat, Inc. v. Mobile Towing Co., 534 F.2d 1172, 1175 (5th Cir. 1976).

${ }^{34}$ Section 16 provides that "[a]ny person, firm, corporation, or association shall be entitled to sue for and have injunctive relief, in any court of the United States having jurisdiction over the parties, against threatened loss or damage by a violation of the antitrust laws." Clayton Act § 16, 15 U.S.C. § 26 (1976).

ss Hawaii v. Standard Oil Co., 405 U.S. 251, 261 (1972).

s6 Id.

${ }^{37}$ Id. at 261-62. Professor Polinsky compared damage and injunctive remedies in nui- 
ingly, Congress may well have extended the injunctive, and not the damages, remedy to a broader class of plaintiffs "to prevent an antitrust defendant from being subjected to a myriad of treble-damage suits by all those in any way affected by an antitrust violation." ${ }^{\text {"38 }}$ The difference between section 4 and section 16 suggests that the "business or property" language of section 4 is designed to limit its reach.

The severity of imposing treble damages also suggests that Congress meant "business or property" to limit the occasions when section 4 awards are made;";9 "the potency of the remedy implies the need for some care in its application."40 Provisions for multiple damages are classified as "penal" in that their effects are punitive. ${ }^{41}$ Although the canon of construction that penal statutes should be construed strictly ${ }^{42}$ is not the only factor relevant to the interpretation of a statute, ${ }^{43}$ it supports the conclusion that the "business or property" requirement should not be the basis for an expansive construction of section 4 .

sance disputes and noted that injunctions may also be inefficient solutions. One example of such an inefficiency is when a plaintiff obtains an injunction and then "extorts" a large sum from the defendant in return for surrendering the right to enforce the injunction. Since the defendant will be willing to pay a sum slightly less than his entire profit to keep his plant open, the plaintiff may arguably receive more than his actual damages. Polinsky, Resolving Nuisance Disputes: The Simple Economics of Injunctive and Damage Remedies, 32 Stan. L. REv. 1075, 1077 (1980). This inefficiency may mean that society as a whole would be worse off with multiple injunctions than with multiple damage claims. Polinsky concludes, however, that damages are not always better; similar strategic behavior patterns may arise under a damage scheme. Id. at 1111-12. Further, in terms of impact on the individual defendant, the multiple treble damage remedy could have a much greater effect than multiple injunctions.

${ }^{38}$ Pan-Islamic Trade Corp. v. Exxon Corp., 632 F.2d 539, 547 (5th Cir. 1980), cert. denied, 454 U.S. 927 (1981). See also Hawaii v. Standard Oil Co., 405 U.S. 251, 260 (1972) ( $\$ 4$ and 16 "notably different"); id. at 262 ("striking contrast between potential impact of suits for injunctive relief and suits for damages").

s8 Tugboat, Inc. v. Mobile Towing Co., 534 F.2d 1172, 1175 (5th Cir. 1976) (noting that treble damage remedy merits more demanding standing rules). The right to recover treble damages "is an unusual one, the remedy is drastic, and the [antitrust] Acts are to be strictly construed and not to be enlarged by construction." Westor Theatres, Inc. v. Warner Bros. Pictures, Inc., 41 F. Supp. 757, 762 (D.N.J. 1941) (footnotes omitted), quoted in Image \& Sound Serv. Corp. v. Altec Serv. Corp., 148 F. Supp. 237, 239 (D. Mass. 1956).

10 Blue Shield v. McCready, 102 S. Ct. 2540, 2548 (1982).

41 J. Sutherland, Statutes and Statutory Construction $\$ 59.02$ (C. Sands 4 th ed. 1974).

${ }^{42}$ Id. § 59.03.

${ }^{43}$ Id. § 59.06 . 


\section{B. Deterrence Goals of Antitrust Law}

Commentators ${ }^{44}$ and courts $^{45}$ increasingly construe the intent of the antitrust laws to be promotion of allocative efficiency. ${ }^{46}$ The sole function of the private damage remedy of section 4 in this view is to deter potential antitrust violators. ${ }^{47}$ Firms will not violate the law if their gain from the antitrust violation is less than their expected cost, which would include any expected antitrust damages or penalties. ${ }^{48}$ Because an increase in private damage awards would make violations more costly, increasing the number of section 4 suits, hence awards, could serve the deterrent purposes of antitrust law.

The class of harms that section 4's "business" clause may compensate will affect the deterrent effect of the statute. If courts define the clause broadly and allow many unestablished businesses to bring private antitrust suits, the chance that any particular violator will be forced to pay treble damages will increase. Increasing the opportunities for an "injured party to recover damages ...

44 Judge (formerly Professor) Richard Posner and Professor Frank Easterbrook are perhaps the most vocal proponents of this proposition. See R. Posner \& F. EASTERBRook, ANtitrust: Cases, Economic Notes and Other Materials 154 (2d ed. 1981) ("Probably most (but certainly not all) scholars today accept the proposition that the antitrust laws have, or should be treated as having, the sole goal of consumer welfare or efficiency."). See also $\mathrm{R}$. Bork, The Antitrust Paradox 66 (1978) ("The Sherman Act was clearly presented and debated as a consumer welfare prescription.").

4s See, e.g., In re Indus. Gas Antitrust Litig., 681 F.2d 514, 516 (7th Cir. 1982) ("From the class of injured persons suffering an 'antitrust injury' only those parties who can most efficiently vindicate the purposes of the antitrust laws have standing to maintain a private action under § 4."). See generally Reiter v. Sonotone Corp., 442 U.S. 330 (1979); Illinois Brick Co. v. Illinois, 431 U.S. 720 (1977); Hanover Shoe, Inc. v. United Shoe Mach. Corp., 392 U.S. 481 (1968). Professor Page notes that although these three Supreme Court decisions are not expressed in economic terms, they are consistent with an economic interpretation of antitrust damages because they interpret the antitrust statute as a deterrent. Page, Antitrust Damages and Economic Efficiency: An Approach to Antitrust Injury, 47 U. CHI. L. REv. 467, 472-74 (1980).

48 A complete presentation of the economics of antitrust law is beyond the scope of this comment. For a clear explanation of the economic theory of antitrust, see R. Posner, supra note 11.

67 See, e.g., Blue Shield v. McCready, 102 S. Ct. 2540, 2546 n.10 (1982); see R. PosNer, supra note 11, at 221-24; Page, supra note 45, at 472-73. See also Easterbrook, supra note 10, at 319 (arguing that deterrence is the first and probably the only goal of antitrust damages).

18 Page, supra note 45 , at 472 . The economic theory behind treble damages is that damages must be multiplied because the chance of detection is less than certain. If the chance of detection is one in three, treble damages will give the proper incentive because the probable fine, discounted by the likelihood of its imposition, will equal the social cost of the violation. For at least some antitrust violations, the chance of detection is greater than one in three and treble damages are therefore economically excessive. R. POSNER, supra note 11, at 22627. 
[will] provide greater respect for the Act"49 and deter potential violators from engaging in anticompetitive activities. ${ }^{50} \mathrm{~A}$ broad definition of the clause, therefore, appears to be consistent with the deterrence goal of the law. At some point, however, more plaintiffs will seek damages than are necessary to deter violations: while the fear of large penalties will cause fewer people to violate the law, the hope of large treble damage awards will encourage more private plaintiffs to try to apprehend the decreasing number of violators. ${ }^{\text {s1 }}$ Ultimately, the mixed signals sent by the high fine will cause potential plaintiffs to spend an excessive amount of money on section 4 enforcement suits, a wasteful and therefore undesirable result. ${ }^{\mathrm{s} 2}$

4 Maltz v. Sax, 134 F.2d 2, 5 (7th Cir.), cert. denied, 319 U.S. 772 (1943).

so Economists make a similar argument. They note that as the probability of detection and conviction increases, the expected cost of engaging in illegal behavior increases, with the likely effect of deterring possible violations. See Landes \& Posner, The Private Enforcement of Law, 4 J. LEGAL Stud. 1, 4-5, 8-9 (1975).

${ }^{51}$ Id. at 9; see Hawaii v. Standard Oil Co., 405 U.S. 251, 262 (1972) (treble damages encourage private plaintiffs "to serve as 'private attorneys general" ").

52 Landes \& Posner, supra note 50, at 15. See also In re Indus. Gas Antitrust Litig., 681 F.2d 514, 515 (7th Cir. 1982) ("[T]o read § 4's language literally would inevitably lead to excessively complex or numerous suits as well as awards unrelated to the social cost of the antitrust violation.").

Similarly, the availability of a lost-profits, treble-damage remedy for unestablished businesses may encourage inefficient conduct. An entrepreneur who knows of an antitrust violation may plan a business that he knows could not succeed in the face of the antitrust violation. To satisfy the intent and preparedness test, he may complete a contract, see infra note 88 and accompanying text, or he may go so far as to operate the business for a short time. His expectation would be that the treble damage remedy would exceed his investment, if any, in the venture.

The Supreme Court has specifically refused to allow recovery in such cases, however, declaring that a venture "could not be called into being in order to maintain a suit for conduct that made it not pay to be born. Claims for such antenatal detriments are not much favored by the law." Buckeye Powder Co. v. E.I. DuPont De Nemours Powder Co., 248 U.S. 55,64 (1918) (citation omitted). It may, however, be difficult to distinguish such sham operations from ventures initiated in good faith. In Buckeye Powder Co., the Court had no trouble with this issue; the plaintiff there had been a corporate insider of the defendant corporation, having left its employ ostensibly to start his own business. $I d$. at 63 . The facts of the case disclosed that the plaintiff "knew all the elements of the situation before he embarked on the venture, and did not do so until the [defendant] Company had reached the height of its power." Id.

In general, one could distinguish good faith ventures by using a constructive intent test, in which plaintiffs would be presumed to act in good faith. One could guard against fabricated suits by weighing against this presumption plaintiff's actual or imputed knowledge of defendant's violation, the fact that the violation was open and notorious and predated plaintiff's business attempt, and a paucity of acts taken by plaintiff to set up the business.

A helpful analogy is the tort law doctrine of "coming to a nuisance." Standard tort law holds that if an individual acquires land that is harmed by a nuisance that existed before he bought the land, he has as much right as other landowners to sue to remedy the nuisance's 
Excessive private antitrust enforcement can also lead to inefficient levels of deterrence. A properly operating system of private law enforcement will establish fines equal to the social cost of the prohibited activity. In antitrust, the optimal fine is equal to the sum of the monopolist's profit and the deadweight loss of monopoly to society. ${ }^{53}$ When such a fine is imposed, the monopolist will only continue his anticompetitive conduct if the gain in profits and resource savings exceeds this fine. ${ }^{54}$

If a series of unestablished businesses can sue, and in so doing raise the expected fine above the social cost of monopoly, socially beneficial antitrust violations will be needlessly deterred.5 ${ }^{56}$ The difference between optimal deterrence and overdeterrence is not easily stated. Given the large number of people who could claim lost profits to unestablished ventures and the speculative nature of their claims, ${ }^{58}$ however, it seems likely that awarding damages to them all would impose penalties on antitrust violators in excess of the social costs of their violations. Thus, a proper understanding of the deterrence policy underlying the Clayton Act also suggests that section 4 should not be construed too generously.

\section{Private Antitrust Enforcement by the Unestablished BusINEsS}

The language and purposes of section 4 require that some limits be placed on awards for lost profits to unestablished businesses. Judicial requirements that section 4 compensate unique and nonspeculative injuries should guide the selection of specific limita-

disturbance of his rights. W. Prosser, Handbook of the LAw of Torts $\$ 91$, at 611 (4th ed. 1971). Some courts limit this doctrine by requiring the party who came to the nuisance to have done so in good faith and not to have purchased the land solely for the purpose of bringing a vexatious lawsuit. Id.; REstatement (SECOND) of TORTS $\S 840 \mathrm{D}$ comment c, illustration 2 (1979). This doctrine suggests that the fact examination required by the proposed constructive intent test would be a practical way to identify bad faith claims.

${ }^{83}$ R. POSNER \& F. EASTERBRooK, supra note 44, at 550.

B4 The potential antitrust violator will compare the costs and benefits of his action. The benefits of an antitrust violation are his monopoly profits and any cost savings resulting from the combination. An optimal fine, the monopolist's profit plus the deadweight monopoly loss to society (the social cost), will deter violations whenever the deadweight loss of monopoly exceeds the cost savings (the social benefit of the violation). If the fine is larger than optimal, it will deter conduct even when the social benefit of the violation exceeds the social cost. Page, supra note 45 , at 472 .

ss There are arguably "efficient" monopolies that are socially beneficial because of cost savings associated with combination. Excessive private enforcement could lead to the destruction of these efficient monopolies, to society's detriment and contrary to the goals of antitrust. Id.

ss See infra notes 70-80 and accompanying text. 
tions on such awards.

\section{A. Private Enforcement Should Remedy Unique Harms}

Private actions are essential to the enforcement of the antitrust laws. Because the government cannot prosecute every antitrust violation, private enforcement increases the likelihood of penalizing antitrust violations, particularly those that are local in character. ${ }^{57} \mathrm{~A}$ private plaintiff serves the public function of ensuring a competitive economy by bringing antitrust damage suits, and thus he is often referred to as a "private attorney general." function of the private plaintiff, however, is not identical to that of the United States Attorney General. ${ }^{58}$ The private plaintiff's statutory authority is limited to those cases in which he is "injured in his business or property by anything forbidden in the antitrust laws." ${ }^{60}$ That limitation has been expressed as follows:

No private litigant has the right to take upon himself the role of the Attorney General in the enforcement of the antitrust laws .... .

It is the Attorney General who applies for enforcement of the antitrust laws in the public interest. When the private litigant sues, he must establish his right to redress for the particular wrong done to him. ${ }^{81}$

57 2 P. AREeda \& D. TuRner, supra note 3, T 331(b), at 149-50.

${ }^{58}$ Hawaii v. Standard Oil Co., 405 U.S. 251, 262 (1972) (treble damages encourage private plaintiffs "to serve as "private attorneys general" "); Zenith Radio Corp. v. Hazeltine Research, Inc., 395 U.S. 100, 130-31 (1969) (private actions "provide private relief" and serve "the high purpose of enforcing the antitrust laws"); Perma Life Mufflers, Inc. v. International Parts Corp., 392 U.S. 134, 147 (1968) (Fortas, J., concurring) (" 'private attorneys general" ").

${ }_{58}$ The Attorney General has a duty to institute proceedings to prevent and restrain the antitrust violations listed in 15 U.S.C. $\$$ 1-8 (1976), regardless of who will suffer harm from the violations. 15 U.S.C. $\S \S 4,9$ (1976). Additionally, the Attorney General may sue for damages when the United States is injured in its business or property, but the damage award is not tripled. 15 U.S.C. § 15a (1976). The private plaintiff, however, may only sue for damages or injunctive relief when he has suffered or will suffer harm from the violation. 15 U.S.C. §§ 15, 26 (1976 \& Supp. IV 1980).

${ }^{60}$ Clayton Act $\S 4,15$ U.S.C. $\$ 15$ (1976 \& Supp. IV 1980).

61 Zenith Radio Corp. v. RCA, 106 F. Supp. 561, 576 (D. Del. 1952). See also Robinson v. Lull, 145 F. Supp. 134, 137 (N.D. Ill. 1956) (private citizen, unlike Attorney General, must show injury to property). Private plaintiffs also should not be allowed to use their "private attorney general" status to seek evidence to support a hunch or suspicion of a cause of action. Waldron v. Cities Serv. Co., 361 F.2d 671, 673 (2d Cir. 1966), aff'd sub nom. First Nat'l Bank v. Cities Serv. Co., 391 U.S. 253 (1968).

From an economic perspective, some argue that too much emphasis on the private causes of action is inefficient. See R. POSNER, supra note 11, at 227-29. Judge Posner points out, however, that the field of private antitrust actions may be "calming down" compared to 
Too broad a construction of section 4 would be inconsistent with the requirement that the plaintiff allege a harm unlike that done to the general public. ${ }^{62}$

The requirement of a unique injury underlies the Supreme Court's ruling in Illinois Brick Co. $v$. Illinois ${ }^{63}$ that indirect purchasers could not sue under section 4 for the antitrust overcharges passed on to them; ${ }^{64}$ if both the direct and indirect purchasers could recover, the antitrust violator might be forced to pay twice for a single wrong. ${ }^{65}$ In the recent case of Blue Shield v. McCready, ${ }^{88}$ the Court recognized that the risk of duplicative recovery was a "consideration of statutory policy" tions on the availability of the section 4 remedy. ${ }^{68}$

Allowing unestablished businesses to sue for lost future profits risks unjustified multiple recovery. Because the failure rate of new businesses is high, ${ }^{60}$ giving unestablished businesses a cause of action for "business" harms, such as lost profits, would allow many to recover when, absent the violation, only a few would have survived long enough to earn profits. It is likely that the harm of being prevented from starting a business is one shared by many, but only after a venture is established and is harmed in some unique way can a harm to business occur that is different from the harm suffered by the general entrepreneurial public. The cause of action recognized under section 4 , therefore, should be broad enough to

the prior tendency to overprosecute. This suggests that reliance on the private action to deter and punish violators is not totally misplaced. Id. at 229-30. See generally Landes \& Posner, supra note 17, at 605-06.

${ }^{62}$ Brownlee v. Malco Theatres, Inc., 99 F. Supp. 312, 316-17 (W.D. Ark. 1951). Even cases that adopt a broad definition of "business" and use the intent and preparedness test acknowledge that the plaintiff's harm must be different from that done by the defendant to the general public. See id.

This limitation on the private action is supported by efficiency concerns. The larger the group affected by an antitrust violation and the more alike their harms, the more efficient it will be to have the claims argued and decided in one case. The United States Attorney General is probably the most efficient prosecutor in such cases, since he, more than any individual or subgroup of plaintiffs, has resources to collect data about the entire group. Private actions should only be brought when an individual plaintiff is better able than the Attorney General to present evidence of the plaintiff's own unique harm, thus justifying the cost of bringing suit separately. For an expression of concern that the burgeoning use of private actions tends to retard rather than promote competition, see R. POSNER, supra note 11 , at 227-29.

ss 431 U.S. 720 (1977).

of Id. at 745-46.

os Id. at 730-31.

102 S. Ct. 2540 (1982).

67 Id. at 2545.

os Id. at 2545-46.

'See supra note 14. 
protect the interests of unestablished businesses that are able to prove unique injuries, but not so broad as to foster duplicative recoveries.

\section{B. Speculative Damages}

The requirement that there be a unique antitrust injury is related to a concern that damages not be awarded on a speculative basis. ${ }^{70}$ In the early years of antitrust enforcement, courts often refused to award damages to unestablished businesses, characterizing such awards as too speculative:" "If anything is speculative, remote and contingent, it is the net income from a business never begun, upon premises never occupied, during a period of time but partially elapsed."72 The period between the late 1800's and 1939 was one of judicial conservatism during which precise showings of damage were required. ${ }^{73}$

By the middle of this century, however, courts were holding that difficulty of proof would not destroy a right of recovery; proof of the extent of damage did not need to be precise if there was specific proof of the fact of damage. ${ }^{74}$ Once a plaintiff proved he

70 See 2 P. AREeda \& D. Turner, supra note 3, 1335 (a), at 170 ("plaintiffs for whom damages are non-existent or unduly speculative may properly be denied standing altogether"). Whether the plaintiff's theory of damages is speculative is one of the issues on the merits and is unrelated to the issue of standing or to questions of statutory construction. Standing is an inquiry regarding justiciability; as such, its focus is on the parties, not on the issues. Flast v. Cohen, 392 U.S. 83, 99 (1968). See generally C. Wright, A. Miller \& E. COOPER, supra note 18, § 3531 . If one interpretation of "business" would give standing to a broad class of unestablished businesses that have only speculative damage claims, however, that interpretation may, as a matter of statutory construction, be less desirable than a narrower interpretation that saves courts from having to examine and reject each case brought by an unestablished plaintiff. See Blue Shield v. McCready, 102 S. Ct. 2540, 2546-47 n.11 (1982) ("the feasibility and consequences of implementing particular damages theories may, in certain limited circumstances, be considered in determining who is entitled to prosecute an action brought under $\S 4$ ").

On accepted methods for measuring damages, see generally Collen, supra note 17; Hoyt, Dahl \& Gibson, supra note 13; Parker, supra note 13; Rulon, supra note 13; Note, supra note 10.

${ }^{71}$ E.g., Central Coal \& Coke Co. v. Hartman, 111 F. 96, 98 (8th Cir. 1901); see generally Hair v. Barnes, 26 Ill. App. 580, 583-84 (1887) (contract breach; damages too speculative); Red v. City Council, 25 Ga. 386, 390 (1857) (contract breach not found; even if found, dam-* ages too speculative).

72 Kenny v. Collier, $79 \mathrm{Ga} .743,746$ (1887).

35 See Guilfoil, Damage Determination in Private Antitrust Suits, 42 Notre Dame LAw. 647, 647 (1967).

74 Flintkote Co. v. Lysfjord, 246 F.2d 368, 392 (9th Cir.), cert. denied, 355 U.S. 835 (1957); Chiplets, Inc. v. June Dairy Prods. Co., 114 F. Supp. 129, 143-44 (D.N.J. 1953); Timberlake, The Legal Injury Requirements and Proof of Damages in Treble Damage Actions Under the Antitrust Laws, 30 Geo. WASH. L. REv. 231, 254 (1961). 
had been injured by the defendant's activity, the jury was allowed to infer the extent of the harm. Courts today are willing to award damages based on economists' profit projections derived from extrapolation or comparison; nevertheless, most courts continue to denounce speculative damage claims and deny recovery when damage theories are too speculative, even when the fact of damage has been alleged..$^{75}$

It is unclear when an award is speculative under contemporary standards, but most courts require that antitrust awards at least meet the "target area" test, which holds that the injury must occur within the area at which the defendant aimed his violation. ${ }^{78} \mathrm{~A}$ common rationale for this test is that "many remotely situated persons may suffer damage in some degree as the result of an antitrust violation, [but] their damage is usually much more speculative and difficult to prove than that of a competitor who is an immediate victim of the violation." 77 Although some damage awards to unestablished businesses under section 4 are appropriate under that rationale, ${ }^{78}$ lost profit awards to unestablished ventures clearly are not. To make such an award, not only must the court speculate about future losses, as it would in the case of an established business, but it must also hypothesize the very basis upon which future losses ordinarily are calculated..$^{79}$ Whether by the tar-

75 See Chrysler Credit Corp. v. J. Truett Payne Co., 670 F.2d 575, 581-82 (5th Cir. 1982); American Infra-Red Radiant Co. v. Lambert Indus., 360 F.2d 977, 995-96 (8th Cir.), cert. denied, 385 U.S. 920 (1966); Volasco Prods. Co. v. Lloyd A. Fry Roofing Co., 308 F.2d 383, 392 (6th Cir. 1962), cert. denied, 372 U.S. 907 (1963); Herman Schwabe, Inc. v. United Shoe Mach. Corp., 297 F.2d 906, 909-10 (2d Cir.), cert. denied, 369 U.S. 865 (1962); Denver Petroleum Corp. v. Shell Oil Co., 306 F. Supp. 289, 309 (D. Colo. 1969); Siegfried v. Kansas City Star Co., 193 F. Supp. 427, 429-30 (W.D. Mo. 1961), aff'd, 298 F.2d 1 (8th Cir.), cert. denied, 369 U.S. 819 (1962); Delaware Valley Marine Supply Co. v. American Tobacco Co., 184 F. Supp. 440, 445 (E.D. Pa. 1960), aff'd, 297 F.2d 199 (3d Cir. 1961), cert. denied, 369 U.S. 839 (1962). The Supreme Court may have signalled the end of this judicial conservatism in Blue Shield v. McCready, 102 S. Ct. 2540 (1982), where the Court noted that the fear of speculative damages had no application to McCready's suit. Id. at 2547 n.11 ("§ 4 plainly focuses on tangible economic injury," but once such injury is shown, a "cautious approach to speculative, abstract or impractical damages has no application").

${ }^{76}$ Pan-Islamic Trade Corp. v. Exxon Corp., 632 F.2d 539, 548 (5th Cir. 1980), cert. denied, 454 U.S. 927 (1981); Larry R. George Sales Co. v. Cool Attic Corp., 587 F.2d 266, 271 (5th Cir. 1979); Calderone Enters. Corp. v. United Artists Theatre Circuit, Inc., 454 F.2d 1292, 1295 (2d Cir. 1971), cert. denied, 406 U.S. 930 (1972); 2 P. Areeda \& D. Turner, supra note 3 , $\pi 334(\mathrm{c})$, at 165-68.

77 Calderone Enters. Corp. v. United Artists Theatre Circuit, Inc., 454 F.2d 1292, 1295 (2d Cir. 1971), cert. denied, 406 U.S. 930 (1972).

7s See infra notes 90-103 and accompanying text.

78 One method that might be employed to calculate damages in such circumstances is the "yardstick" method. Under this method, the lost earnings of a foreclosed or destroyed business are measured by the earnings realized by a comparable business during the rele- 
get area test or some other device, section 4 should be limited to avoid encouraging or compensating such speculative claims. ${ }^{80}$

\section{Limiting the Scope of Awards to Unestablished BusINESSES}

The language and purposes of the Clayton Act and general considerations of antitrust policy all counsel restraint in awarding damages to unestablished businesses. The need for restraint is best served by compensating unestablished ventures under section 4 only for the losses they suffer to property.

\section{A. Majority Approach}

Most courts consider the damage claims of an unestablished venture as a question of whether there has been an injury to the plaintiff's business. If business injury is found, the courts express

vant time period. See, e.g., Twentieth Century-Fox Film Corp. v. Brookside Theatre Corp., 194 F.2d 846 (8th Cir.) (award based on comparison of theater's profits when operated by plaintiff subject to antitrust violation with profits when operated by defendant), cert. denied, 343 U.S. 942 (1952); Homewood Theatres, Inc. v. Loew's, Inc., 110 F. Supp. 398 (D. Minn. 1952) (plaintiff's profit experience compared to that of another theater), appeal dismissed, 207 F.2d 263 (8th Cir. 1953). Such comparisons are speculative, however, particularly when the businesses being compared are not very similar and when, as with unestablished businesses, the degree of similarity is itself a matter of speculation. See generally Rulon, supra note 13, at 159-63. The Supreme Court nevertheless noted the yardstick test with approval in Bigelow v. RKO Radio Pictures, Inc., 327 U.S. 251, 260 (1946).

so Indeed, it would seem that the target area test would immediately preclude awarding damages to many unestablished businesses. The philosophy of the target area test is that defendants are liable when they subjectively aim their violations at specific plaintiffs. $2 \mathrm{P}$. AREEDA \& D. TuRnER, supra note 3, I 334(d), at 165-66. When a business is not yet established, it is difficult to show that a defendant subjectively intended to harm it. Proponents of the target area test support it precisely because it limits the number of potential plaintiffs. To open the "floodgates" to unestablished businesses would give the same result as allowing non-target area plaintiffs to sue: "an over-kill, due to an enlargement of the private weapon to a caliber far exceeding that contemplated by Congress." Calderone Enters. Corp. v. United Artists Theatre Circuit, Inc., 454 F.2d 1292, 1295 (2d Cir. 1971), cert. denied, 406 U.S. 930 (1972).

It is possible, however, for an unestablished business to be a "target" or "a person against whom the conspiracy was aimed," $i d$. , if, for example, the defendant intended to prevent all competition, present and future, and targeted his violative behavior accordingly. But given the fear of expansive recovery out of which the target area test arose, it is unlikely that unestablished businesses will pass the target area test often.

The continued viability of the target area test is in doubt. In McCready, the Supreme Court constructed a new test to analyze antitrust standing without explicitly evaluating existing tests, such as the target area test. See supra note 18. The court cast doubt on the target area test, stating that "[ $t]$ he availability of the $\$ 4$ remedy to some person who claims its benefit is not a question of the specific intent of the conspirators." Blue Shield v. McCready, 102 S. Ct. 2540, 2548 (1982). Nonetheless, the Court made clear that recovery under $\S 4$ must be limited. See id. at 2545-48; supra note 18. 
a willingness to award the plaintiff damages for lost future profits. ${ }^{81}$ When stated this generally, the majority's approach conflicts with section 4's policy of restraint. The majority's intent and preparedness test, however, allows awards to unestablished businesses only when they demonstrate the following: (1) prior experience in the same field as the prospective venture; (2) affirmative action to begin the proposed venture; (3) an ability to finance the venture; and (4) the completion of contracts relating to the venture. $^{82}$

The intent and preparedness test appears in theory to be too generous. Once the four criteria are met, a court following the test would award lost profits based on predictions of how the nonoperative enterprise might have operated in the future. ${ }^{83}$ This sort of calculation is inherently speculative ${ }^{84}$ and risks producing duplicative awards ${ }^{85}$ and overdeterrence. ${ }^{86}$ In fact, however, the test is most often applied to deny awards. Although ostensibly allowing recovery to a broad class of plaintiffs, the test in effect allows recovery only to operating businesses. ${ }^{87}$

In most instances when courts do award damages under the test, a premise for the award is that the plaintiff has demonstrated a property interest that the defendant's antitrust activities have injured..$^{88}$ In this sense, the result of the intent and preparedness

si See sources cited supra note 7.

*2 See Hayes v. Solomon, 597 F.2d 958, 973 (5th Cir. 1979), cert. denied, 444 U.S. 1078 (1980) (citing Martin v. Phillips Petroleum Co., 365 F.2d 629, 633-34 (5th Cir.), cert. denied, 385 U.S. 991 (1966)).

see supra notes $14-17$ and accompanying text.

st See supra notes 71-72 and accompanying text.

ss See supra notes 63-69 and accompanying text.

so See supra notes 47-56 and accompanying text.

s7 See, e.g., Hayes v. Solomon, 597 F.2d 958, 973-74 (5th Cir. 1979) (plaintiff lacked firm plans, contracts, and finances; hence, plaintiff could not show preparedness), cert. denied, 444 U.S. 1078 (1980); Reaemco, Inc. v. Allegheny Airlines, 496 F. Supp. 546, 554 (S.D.N.Y. 1980) (plaintiff had neither financial resources nor consummated contracts; therefore its venture was a mere "hope"); Laurie Visual Etudes, Inc. v. Chesebrough-Pond's, Inc., 473 F. Supp. 951, 955-56 (S.D.N.Y. 1979) (plaintiff had finances and completed contract but no prior experience in the field it wanted to enter, thus it failed the intent and preparedness test); N.W. Controls, Inc. v. Outboard Marine Corp., 333 F. Supp. 493, 506-08 (D. Del. 1971) (preliminary negotiations do not indicate sufficient intent and preparedness); Delaware Valley Marine Supply Co. v. American Tobacco Co., 184 F. Supp. 440, 444-45 (E.D. Pa. 1960) (unestablished business apparently met intent and preparedness test, but because of its lack of business history, had to rely on a hypothetical profit theory which was too speculative to allow an award), aff'd, 297 F.2d 199 (3d Cir. 1961), cert. denied, 369 U.S. 839 (1962).

ss Courts have held that completed contracts are property that is protected under $\S 4$. North Tex. Producers Ass'n v. Young, 308 F.2d 235, 243 (5th Cir. 1962), cert. denied, 372 U.S. 929 (1963); Waldron v. British Petroleum Co., 231 F. Supp. 72, 86 (S.D.N.Y. 1964). Courts applying the intent and preparedness test look specifically for contracts with banks 
test is illogical because section 4 makes injury to property an independent basis for recovery. If the antitrust violation injured property, the award should be for property losses and not for lost business profits. Moreover, because the test refuses awards to entrepreneurs who suffer demonstrable property losses but who do not satisfy the test's "business" criteria, ${ }^{89}$ the intent and preparedness test unduly restricts awards under section 4.

\section{B. Compensation for Injury to Property}

The deficiencies of the intent and preparedness approach would be eliminated if courts awarded damages to unestablished businesses only for losses to property and refused to make awards for business injuries, such as lost profits. In many situations, the result of this rule will be the same as under an approach that concentrates on "business" harms, for there is a substantial overlap between "business" and "property"; "[w]hen a commercial enterprise suffers a loss of money it suffers an injury in both its 'business' and its 'property.' But neither term is rendered redundant by recognizing" that the two terms can coincide. ${ }^{\circ 0}$ There are harms to property that are not business harms. ${ }^{.1}$

Because the statute is disjunctive, redressing injury to "business or property," it is appropriate to distinguish the two types of injury. Both words must have independent significance: "we must assume that Congress by the use of both words did not use them tautologically by way of unnecessary repetition, but intended

or promoters to secure needed funding, with prospective customers for future sales, with suppliers of vital goods, or with potential partners who have necessary expertise. In the absence of such contracts, the courts argue that plaintiffs have no more than a hope of entering the venture. Martin v. Phillips Petroleum Co., 365 F.2d 629, 633-34 (5th Cir. 1966) (contract to secure financing), cert. denied, 385 U.S. 991 (1966); Peller v. International Boxing Club, 227 F.2d 593, 596 (7th Cir. 1955) (boxing promoter needed contracts with boxers); Laurie Visual Etudes, Inc. v. Chesebrough-Pond's, Inc., 473 F. Supp. 951, 956 (S.D.N.Y. 1979) (marketing contract); N.W. Controls, Inc. v. Outboard Marine Corp., 333 F. Supp. 493, 508 (D. Del. 1971) (contract with suppliers); Image \& Sound Serv. Corp. v. Altec Serv. Corp., 148 F. Supp. 237, 238-39 (D. Mass. 1956) (contract with customers); Pastor v. AT\&T, 76 F. Supp. 781, 784 (S.D.N.Y. 1940) (contract to secure financing).

${ }^{80}$ E.g., Laurie Visual Etudes, Inc. v. Chesebrough Pond's, Inc., 473 F. Supp. 951, 955-56 (S.D.N.Y. 1979) (refusing award); see also Reaemco, Inc. v. Allegheny Airlines, 496 F. Supp. 546, 554 (S.D.N.Y. 1980) (noting that absence of any of the four factors will preclude,recovery under the intent and preparedness test).

${ }^{90}$ Reiter v. Sonotone Corp., 442 U.S. 330, 339 (1979).

-1 See id. ("a consumer not engaged in a 'business' enterprise, but rather acquiring goods or services for personal use, is injured in 'property' [and not in 'business'] when the price of those goods or services is artificially inflated"). 
something more by including" the two together. ${ }^{92}$ The Supreme Court concluded in Reiter $v$. Sonotone Corp..$^{93}$ that Congress's intent is best served by giving the word "property" a wide scope.94 To that end, lower courts have defined "property" expansively. For example, a completed contract is "property" under the Clayton Act, ${ }^{95}$ although contract negotiations do not rise to that level..$^{98}$ Courts have defined property broadly enough to include expenditures to defend against patent infringement suits ${ }^{27}$ and for suits to recover the money that an overcharged customer paid, ${ }^{98}$ but not so broadly as to include within section 4 all state law property interests.99

These broad definitions of property would allow a plaintiff who had actually spent money on a venture to recover three times his expenses from the antitrust violator who prevented the business from operating. By allowing recovery in a broad category of cases, the rule proposed here would eliminate the apparent harshness of forbidding lost profits awards to unestablished businesses. This resolution does not just exchange one loose construction for another, however; it replaces a rule capable of awarding lost profits to a venture that never earned any profits with a rule that compensates only concrete property losses.

By allowing recovery only to plaintiffs who have unique injuries, the rule is consistent with section 4's goal of deterrence and its policy of opening the courts to anyone injured by antitrust violations. ${ }^{100}$ Because it will allow damage awards only for claimants

92 Sullivan v. Associated Billposters \& Distribs. of the United States \& Can., 6 F.2d 1000, 1011 (2d Cir. 1925).

442 U.S. 330 (1979).

24 Id. at 338-39 (citing dictionary to illustrate the broad meaning of "property"). An earlier case held that " 'property' has a wider scope and is more extensive than the term 'business" " and "[l]ess is required to prove 'property' than to prove 'business.' " Waldron v. British Petroleum Corp., 231 F. Supp. 72, 86 (S.D.N.Y. 1964). The court also maintained that "Congress intended this distinction [between business and property] to be meaningful." Id. (footnote omitted).

os See supra note 88.

of Peller v. International Boxing Club, Inc., 227 F.2d 593, 596 (7th Cir. 1955).

${ }^{77}$ See Kearney \& Trecker Corp. v. Cincinnati Milacron, Inc., 403 F. Supp. 1040, 108889 (S.D. Ohio 1975) (legal fees recoverable as harm to either business or property), aff'd, 562 F.2d 365 (6th Cir. 1977).

s8 See Reiter v. Sonotone Corp., 442 U.S. 330, 339 (1979); Chattanooga Foundry \& Pipe Works v. City of Atlanta, 203 U.S. 390, 396 (1906) ("A person whose property is diminished by a payment of money wrongfully induced is injured in his property."). See also Hawaii v. Standard Oil Co., 405 U.S. 251, 273-74 (1972) (Brennan, J., dissenting).

99 See 2 P. AREeda \& D. TuRner, supra note 3, I 334(b).

100 When an unestablished venture cannot demonstrate a loss to business or property as defined in this comment, it may still have been harmed in some sense, but no differently 
who can demonstrate quantifiable, unique injuries to property, the rule will prevent speculative and duplicative awards. ${ }^{101}$ Finally, because the cost of the damage awards for property losses more nearly approximate the social costs of antitrust violations than do lost profit awards, ${ }^{102}$ the rule proposed here poses less of a risk of overdeterrence. ${ }^{103}$

\section{CoNCLUSION}

Most courts focus on the "business" clause of section 4 and use the intent and preparedness test to determine when to make awards to unestablished businesses. In theory, this test allows awards to a broad category of plaintiffs, placing the test in conflict with policies against overdeterrence and speculative or duplicative awards. In practice, the test severely limits the number of plaintiffs who may recover, and in this way it conflicts with section 4's purpose of providing a remedy for anyone injured by antitrust violations. Instead of using the intent and preparedness test to compensate "business" losses, courts should award damages for injuries to property of unestablished businesses. By focusing on concrete property losses, courts can avoid speculative and duplicative awards while also providing a remedy to all parties injured by antitrust violations. Such a rule is also consistent with the statute's

from the public. In these instances, the remedy must be a public one achieved through suit by the Attorney General pursuant to 15 U.S.C. $\$ \S 4,9$ (1976). See United States v. ITT, 349 F. Supp. 22, 27 (D. Conn. 1972) (private individual must show personal stake; Attorney General represents the public interest in federal antitrust proceedings), cert. denied, 410 U.S. 919 (1973); Robinson v. Lull, 145 F. Supp. 134, 137 (N.D. Ill. 1956) (if a member of the public sees a monopoly but is not harmed by it himself, he has no standing to sue; it is the Attorney General's function to bring suit to rectify the matter); supra notes 57-62 and accompanying text. See generally Brownlee v. Malco Theatres, Inc., 99 F. Supp. 312, 316-17 (W.D. Ark. 1951) (no recovery because plaintiff unestablished business's injuries no different from those of the public); Note, Standing to Sue for Treble Damages Under Section 4 of the Clayton Act, 64 Colum. L. Rev. 570, 573-74 (1964) (injury must be different from that suffered as a member of the general public).

${ }^{101} C f$. supra notes 61-80 and accompanying text (discussing speculative and duplicative awards).

${ }^{103}$ The social cost of an antitrust violation includes the total lost profits of those businesses that would have earned profits had there been no antitrust violation. Although an unestablished venture may be precluded from conducting business by an antitrust violation, it also may never have earned profits, even absent an antitrust violation; many new businesses fail for reasons other than antitrust violations, see supra note 14. A system that bases antitrust damage awards on hypothetical lost profits for such ventures will overcompensate plaintiffs relative to the true social costs of the violation. See supra text following note 69. Awards for property losses, but not lost profits, will necessarily be lower and therefore will more closely approximate the social costs of violations.

${ }^{103} \mathrm{Cf}$. supra notes 53-56 and accompanying text (discussing overdeterrence). 
language; it accords independent significance to the "property" clause without distorting the ordinary meaning of "business." Finally, it is consistent with section 4's economic purpose because it will foster an efficient level of deterrence of antitrust violations.

Todd Marcus Young 